\title{
The Increased Susceptibility of Women to Multiple Sclerosis
}

\author{
P. Duquette, J. Pleines, M. Girard, L. Charest, M. Senecal-Quevillon and C. Masse
}

\begin{abstract}
Many diseases with an auto-immune etiology have a skewed sex distribution. In the majority of instances, women are affected more frequently than men. A review of population studies demonstrates that the preponderance of women in multiple sclerosis (MS) is almost constant. We show that this preponderance is further increased in early as well as in late-onset cases, in familial cases as well as in MS twin pairs and that the HLA-DR2 allele, which has been associated with MS in Caucasian populations, is significantly more frequent in women than in men with MS. "Rules" have been established for multifactorial diseases; MS contravenes most of those rules. The skewed sex distribution in MS could be attributed to the known hormonal and gender influences on the immune response, as well as to genetic influences.
\end{abstract}

RÉSUMÉ: Prédisposition accrue des femmes à la sclérose en plaques. La plupart des maladies de type autoimmun ont une répartition inégale selon les sexes. Le plus souvent, plus de femmes que d'hommes sont plus atteintes. Une révision d'études épidémiologiques démontre que les femmes sont constamment plus fréquemment atteintes de sclérose en plaques (SEP) que les hommes. Nous montrerons que cette prépondérance féminine est accrue dans les formes précoces, comme dans les formes tardives de la maladie, dans les formes familiales et chez les couples de jumeaux. De plus, l'allèle HLA-DR2, associé à la SEP dans les populations de race caucasienne, est significativement plus fréquent, dans cette maladie, chez les femmes que chez les hommes. Des règles régissant les maladies multi-factorielles ont été décrites; la SEP n'en respecte presque aucune. La prépondérance féminine dans la SEP pourrait être attribuée aux influences connues des hormones sexuelles sur les réponses immunes, ainsi qu'à des facteurs génétiques.

Can. J. Neurol. Sci. 1992; 19:466-47I

Diseases not involving the genital organs and their appendages should, in theory, be equally distributed among women and men, if exposure to the causative agents is the same. They are not. Multiple sclerosis (MS) is one of many diseases with a skewed sex distribution. The disease is clearly more frequent in women than in men, ${ }^{1}$ but this observation remains largely unexplained. The explanation is probably related to the etiology and many hypotheses have been formulated, but none can be substantiated. Most diseases with a known or alleged auto-immune etiology have an unbalanced sex distribution; ${ }^{2}$ in a majority of cases, women are affected more often than men. Lupus erythematosus is nine times more frequent in women than in men, ${ }^{3}$ thyroid diseases are more frequent in women, ${ }^{4}$ so are rheumatoid arthritis ${ }^{5}$ and myasthenia gravis. ${ }^{6}$ Ankylosing spondylarthritis is four to nine times more frequent in men, ${ }^{7}$ as is periarteritis nodosa. ${ }^{8}$ Sex hormones are thought to influence immune responses. ${ }^{2}$ For example, there are rat strains with a spontaneous disease very similar to lupus which occurs exclusively in females. When females are castrated before puberty, or given male hormones, the disease is prevented; when male rats are given female hormones, they become susceptible to the disease. ${ }^{2}$ Tropical spastic paraparesis is more frequent in women, ${ }^{9}$ and this apparently cannot be accounted for by distinct exposure patterns. Seemingly, men and women, for obscure reasons, react differently to a variety of disease agents. This seems worthy of attention. This paper intends to firmly document the greater frequency of MS in women, to show that this is even more apparent in some categories of the disease, to document that MS contravenes the "rules" formulated for multi-factorial diseases ${ }^{10}$ and to discuss the hypotheses put forward to account for the unbalanced sex ratio.

\section{Materials ANd Methods}

We have reviewed published data, including our own. Twenty-nine epidemiological studies have been summed, ${ }^{11-39}$ as well as twelve family studies ${ }^{40-51}$ and six twin studies. ${ }^{52-57}$ Rules for multi-factorial diseases have been borrowed from Childs and Scriver. ${ }^{10}$

\section{RESULTS}

\section{Epidemiological Studies}

Most epidemiological studies mention that MS is more frequent in women than in men. Thirty surveys originating from 18

From Hôpital Notre-Dame, Montreal

Received October 28, 1991. Accepted April 13, 1992.

Reprint requests to: Dr. Pierre Duquette, Hôpital Notre-Dame, 1560 est, rue Sherbrooke, Montreal, P.Q., Canada H2L 4MI 
countries and dating from 40 years onwards ${ }^{11-39}$ indicated that, from a total of 15,988 patients, 10,202 were women and 5,786 were men, for a woman to man ratio (W:M) of 1.76:1. Only one survey reported a higher figure for men. ${ }^{33}$ In the Canadian population, recruited from $13 \mathrm{MS}$ clinics, from a total of 4,632 patients, 3,118 were women, 1,514 were men, for a $\mathrm{W}: \mathrm{M}$ of 2:1. ${ }^{58}$ Data from individual studies are given in Tables 1 and 2. There is a tendency for older studies to show a more equal sex distribution, while the preponderance of women is more apparent in recent surveys. It has been established that women seek medical attention more often than men do. ${ }^{59.60}$ But also, it is conceivable, with increasing numbers of neurologists and with technological improvements, that a greater proportion of benign cases are ascertained and these are more frequent in women (see below).

We have previously published that early-onset cases are even more common in women than in men. ${ }^{58}$ Of 499 patients whose MS began before age 20,381 were women, while 118 were men, for a W:M of 3.2:1. When compared to the ratio of $2: 1$ for the Canadian population from which it was extracted, the $p$ value is significant at a level of 0.000000001 . In the earlyonset cohort, there was an increased proportion of benign and of relapsing-remitting cases. This higher frequency of women in

Table 1. Summary of Thirty Incidence - Prevalence Studies on MS

\begin{tabular}{|c|c|c|c|c|c|}
\hline \multirow[b]{2}{*}{ Authors } & \multirow[b]{2}{*}{ Year } & \multirow[b]{2}{*}{ Country } & \multicolumn{3}{|c|}{ Population } \\
\hline & & & Total & $\mathbf{F}$ & $\mathbf{M}$ \\
\hline Sutherland & 1956 & Northern Scotland & 127 & 71 & 56 \\
\hline Alter & 1962 & Israel & 282 & 147 & 135 \\
\hline Saint & 1962 & Western Australia & 98 & 54 & 44 \\
\hline Stazio & 1964 & Winnipeg, Man., Canada & 128 & 88 & 40 \\
\hline Chipman & 1966 & Houston, Texas, USA & 67 & 45 & 22 \\
\hline Oltedel & 1966 & Vestfeld, Norway & 127 & 71 & 56 \\
\hline Presthus & 1966 & Romsdal County, Norway & 81 & 40 & 41 \\
\hline Rischbreth & 1966 & South Australia & 351 & 211 & 140 \\
\hline Dean & 1967 & South Africa & 281 & 198 & 83 \\
\hline Stazio & 1967 & New Orleans, Louisiana & 59 & 34 & 25 \\
\hline McCall & 1968 & Australia (Perth,..) & 236 & 148 & 88 \\
\hline McCall & 1969 & West Australia & 122 & 85 & 37 \\
\hline Percy & 1971 & Rochester, Minnesota & 48 & 33 & 15 \\
\hline Dean & 1976 & London, GB (Immigrants) & 3970 & 2511 & 1459 \\
\hline Bennett & 1977 & Ottawa, Ont., Canada & 222 & 155 & 67 \\
\hline Brady & 1977 & Republic of Ireland & 1951 & 1133 & 818 \\
\hline Detels & 1977 & USA (Japanese American) & 15 & 8 & 7 \\
\hline Poser & 1978 & Lower Saxony, Germany & 812 & 520 & 292 \\
\hline Sheperd & 1978 & North East Scotland & 557 & 343 & 214 \\
\hline Kurtske & 1979 & Faroe Islands & 14 & 8 & 6 \\
\hline Hoffman & 1981 & Los Alamos, New Mexico & 27 & 18 & 9 \\
\hline Granieri & 1982 & Southern Italy & 21 & 11 & 10 \\
\hline Hader & 1982 & Saskatchewan, Canada & 201 & 135 & 66 \\
\hline Kurtzke & 1982 & Iceland & 165 & 99 & 66 \\
\hline Gallow & 1983 & Britain (France) & 602 & 397 & 205 \\
\hline Granieri & 1983 & Insular ltaly & 31 & 18 & 13 \\
\hline Kinnunen & 1984 & Finland & 548 & 350 & 198 \\
\hline Larsen & 1984 & Western Norway & 236 & 145 & 91 \\
\hline Granieri & 1985 & Ferrara (Italy) & 176 & 108 & 68 \\
\hline Duquette & 1988 & Canada & 4632 & 3118 & 1514 \\
\hline TOTAL & & & 15988 & 10202 & 5786 \\
\hline
\end{tabular}

early-onset cases probably explains why the average age of onset is usually one year earlier in women than in men in large epidemiological studies.

\section{Late-Onset Cases}

Late-onset cases have their initial manifestations after age 45. Noseworthy has described a late-onset MS population from London, Ontario. ${ }^{61}$ From a total of 606 cases, MS began in 527 before age 51, with a W:M of 2:1, while MS began in 79 after age 50 , with a W:M of $2.4: 1$ (p value for the difference: 0.45 ). In Poser's study, ${ }^{32}$ from a total of 812 cases, MS began in 84 before age 45 or after, with a ratio of $2.7: 1$ (p value for the difference: 0.0118 ). The W:M for the whole Poser's cohort was $2: 1$. This statistically significant increase of the susceptibility of women to MS in the early and in the late-onset groups could be related to puberty and to menopause. In our MS clinic woman population, the age of puberty is spread between ages of 10 and 16 and the age of menopause is spread between ages of 40 and 56 , a normal distribution in both cases. The age of puberty is more difficult to determine with precision in men, but we have not noticed, nor has it been reported, that there is a clear difference from the norm in our MS population.

\section{Familial Cases}

Table 2 lists data from 12 published studies of familial MS.40-51 Overall, 755 individuals were evaluated, 413 women and 342 men (W:M of 1.2:1). 483 were considered clinically unaffected, 237 women and 246 men (W:M of 0.9 ); 272 were considered as having definite or probable MS, with a W:M of 1.8:1. In 24 families with more than one member with MS from our clinic, 62 individuals were considered as having definite or probable MS, 43 women and 19 males, for a W:M of 2.2:1.

Sadovnick et al. have reviewed the influence of gender on the susceptibility to MS in sibships recruited from two large Canadian MS Clinics. ${ }^{62}$ They have not found an increased incidence of like-sexed pairs of relatives concordant for MS. There was no increase in extended HLA-haplotype sharing among members of like-sexed pairs. They conclude that their data does not provide evidence for a relationship between sex and disease susceptibility in relatives concordant for MS. Weitkamp had

\begin{tabular}{lccccccr}
\hline Table 2. Summary of Familial MS in 13 Epidemiological Studies \\
\hline \hline \multirow{2}{*}{$\begin{array}{c}\text { Families } \\
\text { Authors }\end{array}$} & \multicolumn{3}{c}{ Individuals Seen } & \multicolumn{4}{c}{ Affected } \\
Seen & Total & F & M & Total & F & M \\
\hline Alter (1976) & 7 & 43 & 23 & 20 & 17 & 13 & 4 \\
Barroche (1986) & 6 & 22 & 12 & 10 & 12 & 8 & 4 \\
Bird (1975) & 1 & 49 & 16 & 33 & 3 & 1 & 2 \\
Drachman (1976) & 8 & 33 & 13 & 20 & 17 & 9 & 8 \\
Eldridge (1978) & 7 & 48 & 27 & 21 & 19 & 11 & 8 \\
Ekbom (1966) & 3 & 23 & 9 & 14 & 8 & 4 & 4 \\
Hens (1978) & 11 & 41 & 18 & 23 & 23 & 9 & 14 \\
Olsson (1976) & 5 & 22 & 12 & 10 & 11 & 6 & 5 \\
Pratt (1951) & 15 & 72 & 40 & 32 & 33 & 23 & 10 \\
Stewart (1981) & 13 & 95 & 53 & 42 & 29 & 19 & 10 \\
Turpin (1986) & 5 & 31 & 15 & 16 & 11 & 7 & 4 \\
Visscher (1979) & 12 & 53 & 38 & 15 & 27 & 23 & 4 \\
Duquette (1988) & 24 & 223 & 137 & 86 & 62 & 43 & 19 \\
Total & 117 & 786 & 423 & 363 & 272 & 176 & 96 \\
\hline & & & & & & &
\end{tabular}


reported an increased proportion of like-sexed pairs in relatives with MS..$^{63}$

\section{Twin Studies}

Several large twin studies have now been reported. ${ }^{52-57}$ They all indicate an increased concordance rate for monozygotic twin pairs. Twin studies tend to be biased towards homozygosity and concordance, but this bias can be alleviated by an appropriate recruitment process. It is possible, although not demonstrated, that same sex women twin pairs are more easily recruited than same sex men twin pairs, since women usually collaborate more readily than men do. Consequently, it is conceivable that part of the excess of women in twin studies is due to a recruitment bias, but we doubt that it accounts for the magnitude of the imbalance we are reporting. From a total of 162 reported twin pairs with a specified sex distribution, 78 were monozygotic (W:M 3.8:1) and 84 were dizygotic (W:M 2.7:1). Of 15 monozygotic concordant pairs, 12 were women, three were men, for a W:M of $4: 1$ (Table 3). Unfortunately, even after inquiry, sex distributions were not available for all reported twin pairs. For this reason, Table 3 does not mention sex distribution.

In a study of US male war veterans, out of 21,000 charts of male twins, only $16 \mathrm{MS}$ cases were found in 15 male twin pairs. ${ }^{64}$ An additional veteran had an isolated optic neuritis. This is less than half the expected prevalence in a comparable control population. This brings some indication that maleness has a protective effect on susceptibility towards MS. In addition, the percentage of positive family history among family members of MS Iwins is very high, from $50 \%$ to $60 \%$, in studies that have evaluated this aspect. ${ }^{65.52}$ Somehow, it would seem that gender, twinning, disease transmission among family members and susceptibility to MS are related. This could be an expression of the multiple genes now thought to be involved in the etiology of MS.

\section{HLA-DR2 Distribution According to Gender}

The major histocompatibility complex is a highly polymorphic set of genes situated on the short arm of chromosome 6 . Among many functions, it determines HLA-alleles, i.e., transmembrane glycoproteins found on the surface of all nucleated cells. Many disease associations with HLA-alleles have been described, mainly with auto-immune disorders. MS has been linked, in Caucasian populations, with DR2 and later with DQw $1 .{ }^{66}$ Since chromosome 6 is of the somatic type, its alleles should be equally distributed between sexes. Table 4 describes the distribution of a few HLA-alleles in two MS populations; we have calculated and reported that the HLA-DR2 allele is more frequent in women than in men and that the difference reaches statistical significance in the London, Ontario cohort. ${ }^{67}$ Similar uneven distributions of HLA-alleles according to sex have previously been reported in $\mathrm{MS},{ }^{68}$ in ankylosing spondylitis (in a Pima Indian tribe), ${ }^{69}$ in myasthenia gravis, ${ }^{70}$ as well as in lupus erythematosus. ${ }^{71}$ Possible explanations for this paradox could be the following: interaction between sex and the genes responsible for the major histocompatibility complex; modulation of the immune response by sex factors (genes or hormones); clinical heterogeneity of the disease (there would be, in these groups, an overrepresentation of a particular form of MS, more frequent in women).

\section{Rules for Multifactorial Diseases}

Childs and Scriver have proposed rules applying for multifactorial diseases. ${ }^{10}$ Since a prevailing hypothesis holds that MS is a multifactorial disease, with an unspecified environmental agent acting on an hereditary predisposition, ${ }^{1} \mathrm{MS}$ should abide by those rules. The main rules are the following:

Cases of early onset are more likely to have affected firstdegree relatives. In our early-onset group, the percentage of

\begin{tabular}{|c|c|c|c|c|c|c|}
\hline \multirow[b]{2}{*}{ Author } & \multirow[b]{2}{*}{ Country } & \multirow[b]{2}{*}{ Total } & \multicolumn{2}{|c|}{ Monozygotic } & \multicolumn{2}{|c|}{ Dizygotic } \\
\hline & & & Concord. & Non-conc & Concord. & Non-conc \\
\hline Bobowick (1978) & $\begin{array}{l}\text { U.S.A. } \\
\text { (Veteran) }\end{array}$ & 9 & $1 \mathrm{M}$ & $4 M$ & 0 & $4 \mathrm{M}$ \\
\hline Cendrowski (1973) & Poland & 5 & 0 & 0 & 0 & $2 \mathrm{~W}, 3 \mathrm{M}$ \\
\hline Currier (1982) & U.S.A. & 51 & 8 & 14 & 3 & 26 \\
\hline Ebers (1986) & Canada & 70 & 7 & 20 & 1 & 42 \\
\hline Kinnunen (1987) & Finland & 21 & $1 \mathrm{~W}$ & $4 \mathrm{~W}, 6 \mathrm{M}$ & 0 & $8 \mathrm{~W}, 2 \mathrm{M}$ \\
\hline Williams (1986) & U.S.A. & 24 & 6 & $5 \mathrm{~W}, 1 \mathrm{M}$ & 2 & $6 \mathrm{~W}, 4 \mathrm{M}$ \\
\hline
\end{tabular}

Table 4. Distribution of HLA According to Sex

\begin{tabular}{|c|c|c|c|c|c|c|c|c|}
\hline \multirow[b]{3}{*}{ HLA Alle le } & \multicolumn{4}{|c|}{ Montreal } & \multicolumn{4}{|c|}{ London, Ontario } \\
\hline & \multicolumn{2}{|c|}{ Patients } & \multicolumn{2}{|c|}{ Controls } & \multicolumn{2}{|c|}{ Patients } & \multicolumn{2}{|c|}{ Controls } \\
\hline & $\% \mathbf{M}$ & $\% \mathrm{~F}$ & $\% \mathbf{M}$ & $\% \mathrm{~F}$ & $\% \mathrm{M}$ & $\% \mathrm{~F}$ & $\% \mathrm{M}$ & $\% \mathrm{~F}$ \\
\hline A3 & 26.9 & 39.8 & 28 & 27.6 & 29.5 & 30.3 & 30.9 & 29.7 \\
\hline B7 & 30.7 & 37.3 & 23.8 & 18.6 & 37.7 & 47.9 & 24.5 & 22.4 \\
\hline DR2 & 43.2 & $53.2 *$ & 23.3 & 19.6 & 35.7 & $62.2+$ & 30.9 & 29.7 \\
\hline DR3 & 31.1 & 26.6 & 14 & 21.7 & 36.1 & 24.4 & 30.6 & 24.3 \\
\hline
\end{tabular}

$* \mathrm{P}=.4$

$+\mathrm{P}<.008$ 
patients with a positive family history is $17 \%$, which is less than the $20 \%$ figure reported in a Canadian study. ${ }^{58}$

Cases of early onset should express the disease more severely. In the same group, after an average duration of disease of 15 years, $76 \%$ of patients were not restricted to a wheel-chair, thus indicating a rather mild to moderate course.

Early onset, severity and increased incidence of affected relatives should characterize cases of the less frequently affected sex. In our study, women were much more frequently affected in the early-onset group and their evolution was milder. There was also an excess of women if all affected members of MS families were pooled, as mentioned in 3.

Late-onset cases are milder, more readily preventable, more responsive to treatment. In MS, late-onset cases have a more rapidly progressive evolution than earlier onset $\operatorname{cases}^{18}$ and do not respond better to treatment than other groups.

Concordant twin pairs are more likely to have a positive family history. This is true for MS, as indicated in 4.

Only one of five rules applies in MS. Either the rules are non valid, or MS is not a multifactorial disease.

\section{Discussion}

In summary, we have documented the preponderance of women in the distribution of MS according to gender and presented evidence that this preponderance is further increased in early and late-onset cases, in familial cases and in twins; in addition, the HLA-DR2 allele is significantly more frequent in affected women than in affected men. We have shown that only one of five rules proposed for multifactorial diseases applies for MS. In a way, the increased susceptibility of women to MS "overrides" all other susceptibility factors and seems to be an important element in the predisposition to the disease,

Hormonal factors are usually proposed to explain skews in gender distribution, especially for auto-immune diseases. Although immune abnormalities, the most consistent being an excess production of immunoglobulins in the cerebrospinal fluid, have been described,' MS has not been proven to be an auto-immune disorder. The putative antigen(s) against which the elevated antibodies are directed has (have) not been identified. In addition, MS is not associated with other auto-immune diseases, as is commonly the case for diseases in that category; autoantibodies, a feature common to auto-immune disorders, have not been found in MS patients. Hormonal disturbances have not been reported either and our clinical experience with MS has not revealed obvious evidence of gonadal dysfunction. In particular, when evaluating the diseases associated with MS (as part of another study, to be submitted), we have not encountered an unexpected number of patients with ovarian disease, menstrual irregularities, decreased fertility, miscarriages, or with a primary sexual dysfunction. Another indication that sex hormones may be involved in the pathogenesis of MS is that clinical manifestations in women often run in parallel with changes in the estrogen-luteinizing hormone balance as occur during the menstrual cycle, after pregnancy and during the climacterion. ${ }^{72}$

It could then be assumed, given the apparently normal status of gonadal function, that "normal" sex hormones act on a genetically abnormal immune system or alter the expression of genetic susceptibility factors. The influence of gender and sex steroids on the immune response has been reviewed. ${ }^{2}$ Women are known to have higher levels of immunoglobulins than men and a decreased cell-mediated immunity; natural killer (NK) cell activity is decreased during the peri-ovulatory period and interleukin- I (IL-1) production is modified in vitro by estrogens and progesterone. The presence of cytoplasmic receptors for estrogens and androgens in lymphoid cells, or in the thymic matrix, may explain why these sex hormones are able to modify the function of these organs and to interact with the immune system and regulate it.

Prostaglandins could also mediate the effect of sex hormones on immunity. Progesterone acts on the endometrium, causing it to secrete mucus, vasoactive substances, and prostaglandins. Prostaglandins are known to have both pro- and anti-inflammatory effects through lipoxygenase and cyclo-oxygenase products, respectively. ${ }^{73}$

There is no indication that a gene on the $\mathrm{X}$, or the $\mathrm{Y}$, chromosome is involved in MS. Disease transmission is certainly not of a X-linked type and MS is not associated with other X-linked disorders. Linkage studies using probes for the $X$ chromosome have been negative (GC Ebers, personal communication). Mitochondrial diseases are transmitted by affected mothers to children of both sexes. Affected MS mothers transmit the disease to their progeny more often than affected fathers do, but we have well documented examples of father-to-child transmission, thus discarding the possibility of a mitochondrial gene in the transmission of MS. Tourette's syndrome is a further example of a genetic disorder which, although reportedly attributable to a single autosomic dominant gene, is three times more frequent in men than in women. ${ }^{74}$

In conclusion, women have a definitely increased susceptibility to MS. This is clear in the gender distribution of global patient populations, and in familial studies as well. The number of twin pairs with known sex distribution, although small, indicate an increased concordance rate in women. We cannot offer a definitive explanation for these observations. Sex hormones, through their effect on the immune response, may be involved. Genetic factors could also be operative. Obviously, we will have to know more about the interaction of multiple genes, and nongenetic factors, in the acquisition of diseases which, like MS, are not monogenic disorders.

\section{ACKNOWLEDGEMEN'T}

The authors wish to express their gratitude to Dr. G.C. Ebers for his support and helpful comments in the preparation of this manuscript.

\section{REFERENCES}

1. Francis GS, Antel JP, Duquette P. Inflammatory demyelinating diseases of the CNS. In: Bradley WG, Daroff B, Fenichel GM, Marsden CD, eds. Neurology in Clinical Practice. Boston: Butterworth Publishers, 1990; 1150.

2. Schuurs AH, Verheul HA. Effects of gender and sex steroids on the immune response. J Steroids Biochem 1990; 35(2): 157-172.

3. Ward MM, Studenski S. Systemic lupus erythematosus in men: a multivariate analysis of gender differences in clinical manifestations. J Rheumatol 1990; 17(2): 220-224.

4. Blumenthal HT, Perlstein IB. The aging thyroid. I. A description of lesions and an analysis of their age and sex distribution. J Am Geriatr Soc 1987; 35(9): 843-854.

5. Khan MA, Yamashita TS, Reynolds TL, et al. HLA-DR4 genotype frequency and gender effect in familial rheumatoid arthritis. Tissue Antigens 1988; 31(5): 254-258. 
6. Rey RD, Sanz OP, Fernandez JM, et al. Diagnosis and treatment of myasthenia gravis: study of an inpatient population. Arq Neuropsiquiatr 1990; 48(3): 270-278.

7. Gran JT, Husby G, Hordick M. Prevalence of ankylosing spondylitis in males and females in a young middle-aged population of Tromso, northern Norway. Ann Rheum Dis 1985; 44: 359-367.

8. Michel CJ. Epidemiology of vasculitis. Rheumat Dis Clin of N Am 1990; 16(2): 261-268

9. Roman GC, Spencer PS, Schoenberg BS, et al. Tropical spastic paraparesis in the Seychelles Islands: a clinical and case-control neuroepidemiologic study. Neurology 1987; 37: 1323-1328.

10. Childs B, Scriver CR. Age at onset and causes of disease. Perspect Biol Med 1986; 29: 437-460.

11. Alter M, et al. Multiple sclerosis in Israel: prevalence among immigrants and native inhabitants. Arch Neurol 1962; 7: 253-263.

12. Bennett $P$, et al. Survey of persons with MS in Ottawa; 1974-1975. Can J Public Health 1977; 68: 141-147.

13. Brady R, et al. Multiple sclerosis in the Republic of Ireland. Irish Med J 1977; 70: 500-506.

14. Chipman M: Multiple sclerosis in Houston, Texas; 1954-1959. Acta Neurol Scand 1966; 42 (Suppl 19): 77-82.

15. Dean G, et al. Annual incidence, prevalence and mortality of multiple sclerosis in white South-African born and white immigrants to South Africa. Br Med J 1967; 2: 724-730.

16. Dean $\mathrm{G}$, et al. Multiple sclerosis among immigrants in Greater London. Br Med J 1976; 1: 861-864.

17. Detels R, et al. Evidence of lower susceptibility to multiple sclerosis in Japanese Americans. Am J Epidemiol 1977; 105: 303-310.

18. Gallow $M$, et al. Epidémiologie de la sclérose en plaques en Bretagne. Presse Médicale 1983; 12: 995-999.

19. Granieri E, Rosati G. Italy, a medium or high risk area for multiple sclerosis? An epidemiologic study in Barbagna, Sardinia, southern Italy. Neurology 1982; 32: 466-472.

20. Granieri E, et al. The frequency of multiple sclerosis in Mediterranean Europe. An incidence and prevalence study in Barbagna, Sardinia, insular Italy. Acta Neurol Scand 1983; 68: 84-89.

21. Granieri E, et al. The frequency of multiple sclerosis in Italy - a descriptive study in Ferrano. Ann Neurol 1985; 17:80-84.

22. Hader WJ. Prevalence of multiple sclerosis in Saskatoon. Can Med Assoc J 1982; 127: 295-297.

23. Hoffman RE, et al. Increased incidence and prevalence of multiple sclerosis in Los Alamos County, New Mexico. Neurology 1984; 34: 1457-1492.

24. Kinnunen E. Multiple sclerosis in Finland, evidence of increasing and uneven geographic distribution. Neurology 1984; 34 : 457461 .

25. Kurtzke JF, Hyllested K. Multiple sclerosis in the Faroe Islands. I. Clinical and epidemiological features. Ann Neurol 1979; 5: 6-21.

26. Kurtzke JF, et al. Multiple sclerosis in Iceland. I. Evidence of a postwar epidemic. Neurology 1982; 32: 143-150.

27. Larsen JT, et al. Western Norway - a high risk area for multiple sclerosis: a prevalence/incidence study in the county of Hordaland, Norway. Neurology 1984; 34: 1202-1207.

28. McCall MG, et al. Frequency of multiple sclerosis in three Australian cities: Perth, Newcastle and Mobart. J Neurol Neurosurg Psychiatry 1968; 31: 1-9.

29. McCall MG, et al. The frequency of multiple sclerosis in Western Australia. Acta Neurol Scand 1969; 45: 151-165.

30. Oltedel SI. Multiple sclerosis in Vestfeld, Norway. Acta Neurol Scand 1966; 42 (Suppl 19): 19-26.

31. Percy AK, et al. Multiple sclerosis in Rochester, Minnesota - a sixty year appraisal. Arch Neurol 1971; 25: 105-111.

32. Poser S. Multiple sclerosis - an analysis of 812 cases by means of electronic data processing. Berlin: Springer Verlag, 1978

33. Presthus J. Multiple sclerosis in More og Romsdal County, Norway. Acta Neurol Scand 1966; 42 (Suppl 19): 12-18.

34. Rischbreth RH. The prevalence of disseminated sclerosis in South Australia. Med J Aust 1966; 1: 774-776.

35. Saint EG, Sadka M. The incidence of multiple sclerosis in Western Australia. Med J Aust 1962; 2: 249-250.

36. Sheperd DI, Dourine AW. Prevalence of multiple sclerosis in northeast Scotland. Br Med J 1978; 2: 314-316.
37. Stazio A, et al. Multiple sclerosis in Winnipeg, Manitoba methodological considerations of epidemiological survey: ten years follow-up on a community-wide study and population resurvey. J Chronic Dis 1964; 17: 415-438.

38. Stazio A, et al. Multiple sclerosis in New Orleans, Louisiana, and Winnipeg, Manitoba, Canada. Follow-up of a previous survey in New Orleans and comparison between the patient populations of the two communities. J Chronic Dis 1967; 20: 311-332.

39. Sutherland M. Observations on the prevalence of multiple sclerosis in northern Scotland. Brain 1956; 1979: 455-483.

40. Alter M, Harsche M, Anderson VE, et al. Genetic association of multiple sclerosis and HL-A determinants. Neurology 1979; 29: 1354-1360.

41. Barroche G, Perrier P, Raffoux C, et al. HLA et sclérose en plaques familiale. Rev Neurol (Paris) 1986; 142(10): 738-745.

42. Bird TD. Apparent familial multiple sclerosis in three generations. Arch Neurol 1975; 32: 414-416.

43. Drachman DA, Davidson WC, Mittal KK. Histocompatibility (HLA) factors in familial multiple sclerosis. Arch Neurol 1976; 33: 406-413.

44. Eldridge R, McFarland H, Sever J, et al. Familial multiple sclerosis: clinical histocompatibility and viral serological studies. Ann Neurol 1978; 3: 72-80.

45. Ekbom K. Familial multiple sclerosis associated with narcolepsy. Arch Neurol 1975; 15: 337-416

46. Hens L, Carton H. HL-A determinants and familial multiple sclerosis: HL-A typing of 13 families with at least two affected members. Tissue Antigens 1978; 11: 75-80.

47. Olsson JE, Möller E, Link H. HLA haplotypes in families with high frequency of multiple sclerosis. Arch Neurol 1976; 33: 808-812.

48. Pratt RTC, Compston ND, McAlpine D. The familial incidence of disseminated sclerosis and its significance. Brain 1951; 74: 191-232.

49. Stewart GJ, McLeod JG, Basten A, et al. HLA family studies and multiple sclerosis: a common gene, dominantly expressed. Hum Immunol 1981; 3: 13-29.

50. Turpin JC, Dubois D, Delasnerie-Lauprêtre N. La prédisposition familiale à la sclérose en plaques. Rev Neurol (Paris) 1986; 142(5): 509-516.

51. Visscher BR, Detels R, Dudley J, et al. Genetic susceptibility to multiple sclerosis. Neurology 1979; 29: 1354-1360.

52. Bobowick AR, Kurtzke JF, Brody JA, et al. Twin study of multiple sclerosis: an epidemiologic inquiry. Neurology 1978; 28: 978987.

53. Cendrowski WS. Multiple sclerosis in twins and other relatives. Acta Neurol Scand 1973; 49: 552-556.

54. Currier RD, Eldridge R. Possible risk factors in multiple sclerosis as found in a national twin study. Arch Neurol 1982; 39: 140-144.

55. Ebers GC. Bulman DE, Sadovnick DA, et al. A population-based study of multiple sclerosis in twins. $\mathrm{N}$ Engl J Med 1986; 315: $1638-1642$.

56. Kinnunen E, et al. Multiple sclerosis in a nationwide series of twins. Neurology 1987; 37(10): 1627-1629.

57. Williams A, Eldridge $\mathrm{R}$, McFarland $\mathrm{H}$, et al. Multiple sclerosis in twins. Neurology 1980; 30: 1139-1147.

58. Duquette P, Girard M, Pleines J. Aspects of the women predominance in multiple sclerosis $1987 ; 111: 359-363$.

59. Plascencia A, Ostfeld AM, Gruber SB. Effects of sex on differences in awareness, treatment and control of high blood pressure. Am J Prev Med 1988; 4(6): 315-326.

60. Stewart WF, Celentano DD, Linet MS. Disability, physician consultation and use of prescription medications in a population-based study of headache. Biomed Pharmacother 1989; 43(10): 711-718.

61. Noseworthy J, Paty D, Wonnacott T, et al. Multiple sclerosis after age 50. Neurology (Cleveland) 1983; 33: 1537-1544.

62. Sadownick AD, Bulman DE, Hashimoto $L$, et al. The influence of gender on the susceptibility to multiple sclerosis in sibships. Arch Neurol 1991; 48: 586-588

63. Weitkamp LR. Multiple sclerosis susceptibility: interaction between sex and HLA. Arch Neurol 1983; 40: 399-401.

64. Kurtzke JF, Beebe GW, Norman JE. Epidemiology of multiple sclerosis in U.S. veterans. 1. Race, sex and geographic distribution. Neurology (NY) 1979; 29(9): 1228-1235.

65. Myrianthopoulos NC. Genetic aspects of multiple sclerosis. $\mathrm{ln}$ : Koestier JC, ed. Handbook of Clinical Neurology: 
Demyelinating Diseases. New York: Elsevier, 1985; 3(47): 10: 289-317.

66. Compston A, Ebers G. The genetics of multiple sclerosis. In: Cook SD, ed. Handbook of multiple sclerosis. New York: Marcel Dekker, Inc, 1990; 25-39.

67. Charest L, Duquette P. Interaction between sex and HLA in a population study. Arch Neurol 1984; 41: 704.

68. Poskanzer DC, Terasaki PI, Prenney LB, et al. Multiple sclerosis in the Orkney and Shetland Islands. III. Histocompatibility determinants. J Epidemiol Commun Health 1980; 34: 253-257.

69. Calin A, Berrnett PH, Jupiter J, et al. HLA B-27 and sacro-iliitis in Pima Indians: association in males only. J Rheumatol 1977; 3(Suppl): 44-48.

70. Pirskanen R. Genetic associations between myasthenia gravis and the HLA system. J Neurol Neurosurg Psychiatry 1976; 39: 2333.
71. Bell DA, Rigby R, Stiller CR, et al. HLA antigens in systemic lupus erythematosus: relationship to disease severity, age at onset and sex. J Rheumatol 1984; 11: 475-479.

72. Lewis GP. Immunoregulatory activity of metabolites of arachidonic acid and their role in inflammation. Br Med Bull 1983; 39: 243248.

73. Van Lambalgen $R$, Sanders EA, D'Amaro J. Sex distribution, age at onset and HLA profiles in two types of multiple sclerosis. A role for sex hormones and microbial infections in the development of autoimmunity? J Neurol Sci 1986; 76: 13-21.

74. Devor EJ. Untying the gordian knot: the genetics of Tourette syndrome. J Nerv Ment Dis 1990; 178: 669-679. 